\title{
WD Repeat-Containing Protein 5
}

National Cancer Institute

\section{Source}

National Cancer Institute. WD Repeat-Containing Protein 5. NCI Thesaurus. Code C132136.

WD repeat-containing protein 5 (334 aa, $\sim 37 \mathrm{kDa}$ ) is encoded by the human WDR5 gene. This protein plays a role in post-translational modification of histone proteins. 